\title{
鳥取県東部・中部地域の発震機構の研究
}

\author{
鳥取大学土木工学科* 西 山浩史・西田良平 \\ 京都大学防災研究所地震予知研究センター** 中 尾 節 郎
}

\section{Study of Focal Mechanisms in Eastern and Central Areas of Tottori Prefecture}

\author{
Hiroshi Nishiy ama and Ryohei Nishida \\ Department of Civil Engineering, Tottori University, 4-101, \\ Koyama-cho minami, Tottori 680-0945, Japan \\ Setsuro NAKaO \\ Tottori Observatory, Disaster Prevention Research Institute, Kyoto \\ University, 1-286-2, Kitazono, Tottori 680-0004, Japan
}

(Received April 12, 1999; Accepted August 16, 1999)

\begin{abstract}
The tectonic stress, which was found from focal mechanisms of earthquakes in the eastern and the central area of Tottori prefecture, were investigated. Focal mechanisms in this area were the strike slip type of WNW-ESE compression, which is nearly agreed with the mechanism of the 1943 Tottori earthquake. Tectonic stress in this area has conserved the same pattern as the Tottori earthquake, 1943. But the seismic activity near the Yoshioka-Shikano faultsystem shows lower than the other regions. Though their focal mechanisms show a large irregularity, the averaged P-axis indicates NW-SE compression compatible with the strike of the Yoshioka-Shikano faultsystem. This may be attributed to the situation that this area agrees approximately with the bright spots of the 1943 Tottori earthquake.
\end{abstract}

Key words: Focal mechanism, The 1943 Tottori earthquake, Tectonic force.

\section{§1.はじめに}

山陰地域は西南日本内帯で, 大山, 三瓶山, 神鍋山な ど第四紀火山がベルト状に点在し, 地震活動も海岸に 沿った活動域を示す, 地壳上部の活構造の見られる地域 である. マグニチュード 7 以上の大地震では 1884 年浜 田地震, 1925 年北丹後地震, 1943 年鳥取地震が海岸地 域に発生している [浜田 (1987)].

鳥取地方では, 鳥取地震 ( $M 7.2$ ) が 1943 年 9 月 10 日に起こり, ほぼ東西走向の吉岡断層・鹿野断層が地上 に現れ [西田・他 (1993)], 余震が県東部・中部の広い 範囲に発生し，震源断層は約 $32 \mathrm{~km}$ の長さで海岸にほ ぼ平行であると推定されている [KANAMORI (1972)]. 1976 年から詳細な微小地震観測が京都大学防災研究所

* 干680-0945 鳥取市湖山町南 4丁目 101 番地

** \%680-0004 鳥取市北園 1 丁目 286-2
地震予知研究センター鳥取観測所（以下「鳥取観测所」 と略す）で実施され，震央分布は鳥取地震の震源断層に 沿った線状配列を示している (Fig. 1). しかし，1983 年 鳥取県中部の地震 $(M 6.2)$ はその走向に共役な断層系に 発生し, 微小地震から見た地下断層系の活動は複雑であ る.

地表面の活断層に沿った地震は発震機構の解析などか ら同じ応力場における地下断首系の活動と解明され, 今 まで山崎断層地域をはじめ多くの研究 [KISHIMOTo and NishidA (1973), 西田 (1983)] がなされている.この地 域は微小地震観測の充実による精度の高いデータの蓄積 がなされ, 断層周辺の応力場の詳細な議論が可能となっ ている.

今までの研究で, 西南日本内帯に属する山陰地域の応 力場は山崎断層系などの近畿地方の断層系と少し異な り, 鳥取地震の主応力方向に代表されるように東西方 


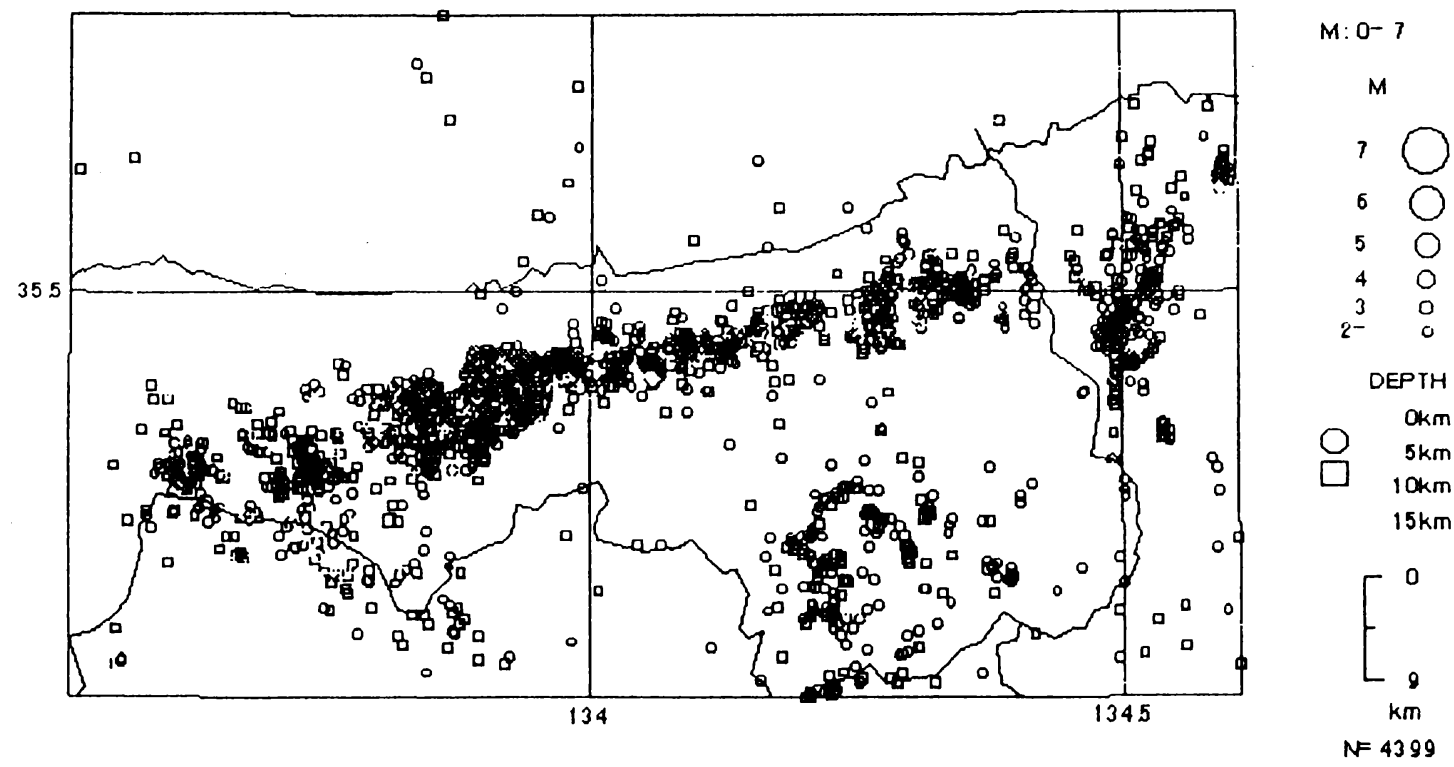

Fig. 1. Hypocenter distribution of earthquakes $(M \geqq 2.0)$, which was determined routinely by the Tottori Observatory during the period from Jan. 1977 to Nov. 1997.

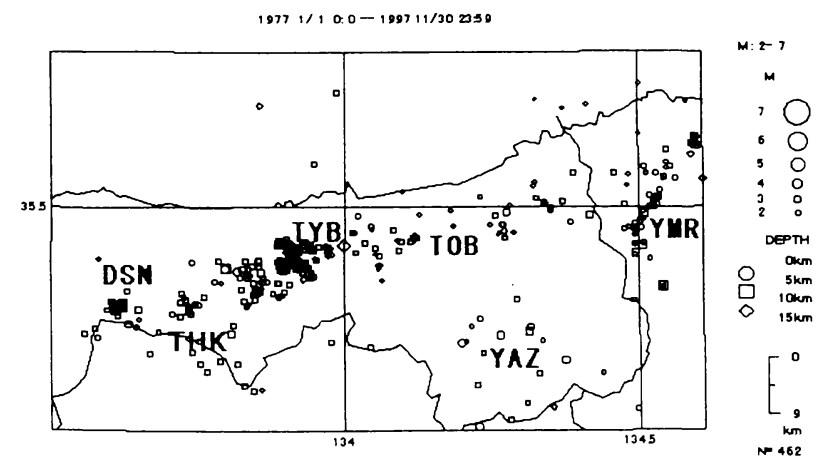

Fig. 2. Hypocenter distribution of earthquakes, which were used for a focal mechanism analysis, and codes to each area. DSN; near Mt. Daisen, THK; Tohhaku, TYB; Central area, TOB; Eastern area, YAZ; Yazu area, YMR; Northwestern of Hyogo area.

向から時計廻りに少し回転した応力場を示している [Nishida (1973), 伊藤 (1990), KATAo et al. (1995)]. 今 回は鳥取観測所にテレメータシステムが導入された翌年 の 1977 年 1 月から 1997 年 11 月までのデー夕に基づ いて, 微小地震の発震機構解を決定した. そして, 発震 機構に基づき, 鳥取県東部・中部地域及び周辺域の広域 応力場について議論する.

\section{§2. 鳥取県東部中部及ひ周辺地域の地震活動}

発震機構について述べる前に, この地域の地震活動を 概観しておく. 1977 年 1 月から 1997 年 11 月までの鳥 取県東部・中部及び周辺地域における微小地震分布は, 海岸沿いの線状配列が顕著である (Fig. 1). しかし詳細
に見ると，その活動は 1 つの連続した活動域ではなく， 活動域之空白域が見られ，線状配列む一律ではない［西 田・他 (1976)]. 鳥取地震の震源断層は長さ約 $32 \mathrm{~km}$ と 推定され，東部から中部地域に及んでいる. 中部地域を 大山付近 (DSN), 東伯 (THK), 中部 (TYB) に分け, 東部 地域を東部 (TOB) と八頭 (YAZ), 兵庫県西北部 (YMR) に分けて, 地域別にそれぞれの微小地震活動の特徴につ いて述べる (Fig. 2).

鳥取県の大山付近 (DSN) は, この活動域の西の端に位 置し, 大山火山下の地震活動の空白域に隣接している. この地域は他の地域に比べると活動の低い地域である. 1985 年 6 月 26 日に $M 3.5$ の地震から始まり, 7 月 2 日の $M 4.7$ を本震とする活動が 9 月まで続いた [竹内・ 


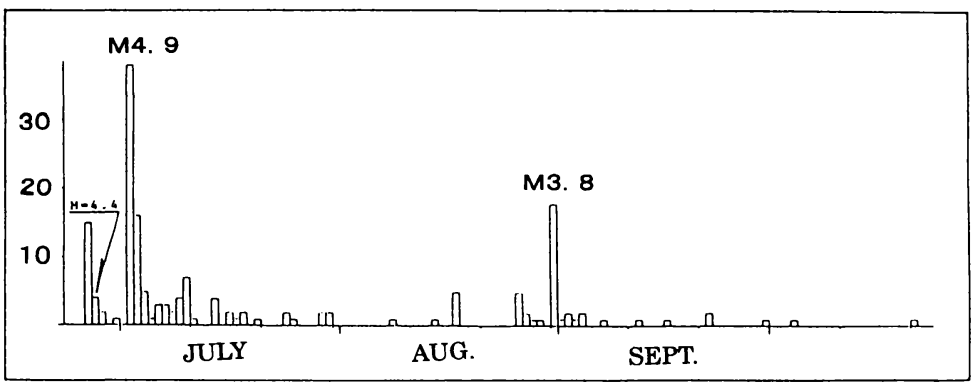

Fig. 3. Frequency distribution of earthquakes in DSN area is shown whose hypocenters were determined by the Tottori Observatory, from June to October 1985.

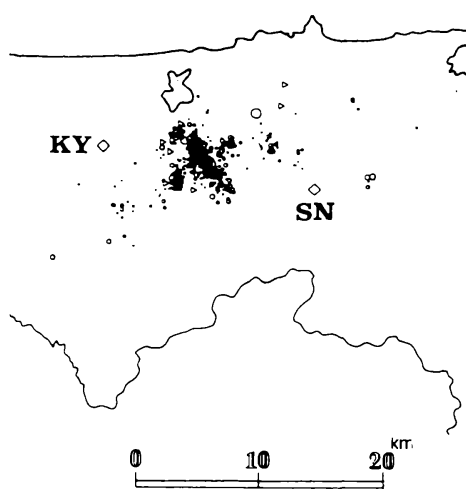

Fig. 4. Hypocenter distribution of aftershocks of the 1983 Tottori earthquake from Oct. 1983 to Dec. 1984. Kurayashi (KY), Shikano (SN), Tottori (TT) and Chizu (CZ) are seismic stations of the Tottori Observatory.

他 (1986)]。この間, 地震活動が休息していた時期 (7 月 中旬〜8 月中旬) に関金町野添で地鳴りが聞こえた (Fig. 3). 発震機構の解析では, 地殼応力が東西方向から時計 回りに回転する時間的変化があり, 活動した断層系が違 うと解釈されている [松山 (1989)].

東伯地域 (THK) は地震活動が定常的に発生して, 目 立った活動はなく，比較的広範囲に分布している，地震 活動が一番活発な中部地域 (TYB) では, 吉岡・鹿野断 層の延長に沿って活動が帯状に分布している. 1983 年 10 月 31 日の 01 時 51 分に鳥取県中部地震 $(M 6.2)$ が 鳥取県中部地域, 三朝町之東郷町の町境, 波関峠の下 10 $\mathrm{km}$ に発生した，鳥取地震以来最大の地震である。震央 近傍の倉吉市で鉄筋コンクリートの市役所が一部分破損 する被害を受けている．当時倉吉には震度観測がなく， 鳥取で最大震度 4 を記録している. その 3 分半後に東へ 約 $6 \mathrm{~km}$ 離れた青谷町で $M 5.7$ の地震が発生した.これ らは 1943 年の鳥取地震 (M 7.2) の余震域のほぼ西端に 位置している [NISHIDA $(1988,1990)]$.

余震域は NW-E の走向のほぼ垂直な震源断層周辺の

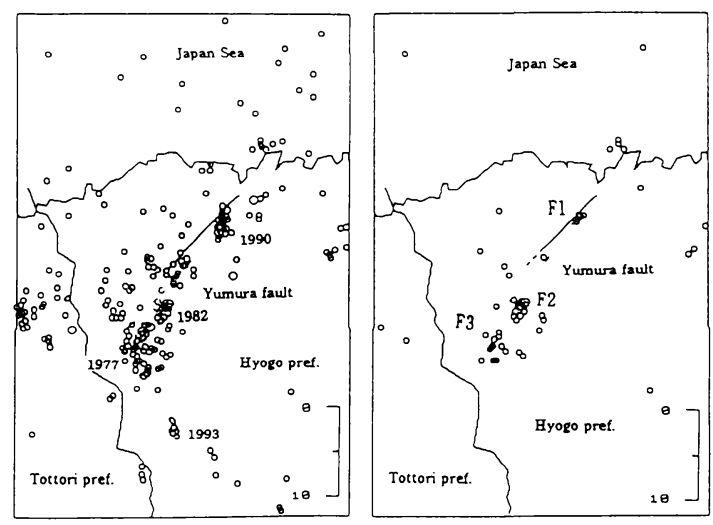

Fig. 5. Hypocenter distribution of the northwestern Hyogo area. Left: Migration of seismic activity from southwest to northeast during the period from 1976 to 1993. Right: Migration of seismic activity from northeast to southwest during the period in 1994, F1 (March), F2 (May) and F3 (Dec.).

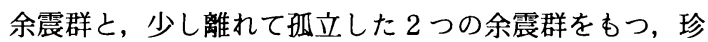

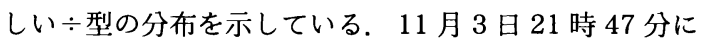
最大余震 (M 4.7) が余震域の北西端に発生した (Fig. 4). 鳥取地震の地震断層（余震分布）は ENE-WSW 走向で あるが, 本震の震源断層はそれに共役な断層系である. また, 最大余震の走向は本震の震源断層に共役な走向 $\mathrm{NE}-\mathrm{SW}$ である. 主な余震活動は約 1 年間続き, それ以 降は目立った地震は発生していない.

吉岡・鹿野断層周辺の地震活動 (TOB) は, 1977 年〜 1985 年の間に活動が活発化したが, 以後低活動が続い ている. 1977 年の活動では, 吉岡・鹿野断層周辺の数 力所で群発活動が発生し, 1983 年は鳥取県中部地震が 発生し, 誘発されて活発化した. 吉岡・鹿野断層周辺で は地震分布が断層とほぼ同じ走向に線状分布している. 鳥取市から東側では, 地表面に走向の異なる活断層があ り, その走向と地震活動分布が一致していることから, 
地下断層系の違いが微小地震分布に現れていると推定さ れる [瀧谷 (1991)].八頭地域 (YAZ) は海岸に沿った活 動ではなく, 鳥取県東部の内陸に発生している. 南側に 山崎断層があり, 広範囲に地震が分布している. 時々, マグニチュード 4 クラスの地震が発生する.

兵庫県北西部の地震分布 (YMR) は湯村断層の南側に 当たり，鳥取地方の活動域と走向が違っている. 湯村断
層は SW-NE 走向で, 温泉町から浜坂町久斗山付近を通 り香住町付近まで, 約 $10 \mathrm{~km}$ が地質断層として確認さ れている.また，日本の活断層地図 [活断層研究会 (1980)］に「鳥取地震時に活動した鹿野断層の東方延長 上に湯村断層之名付けられた地質断層があり，微小地震 がほぼこれに沿って線上に発生しているが, 活断層地形 を全く示さないのでこれを除外した.」と記載されてい
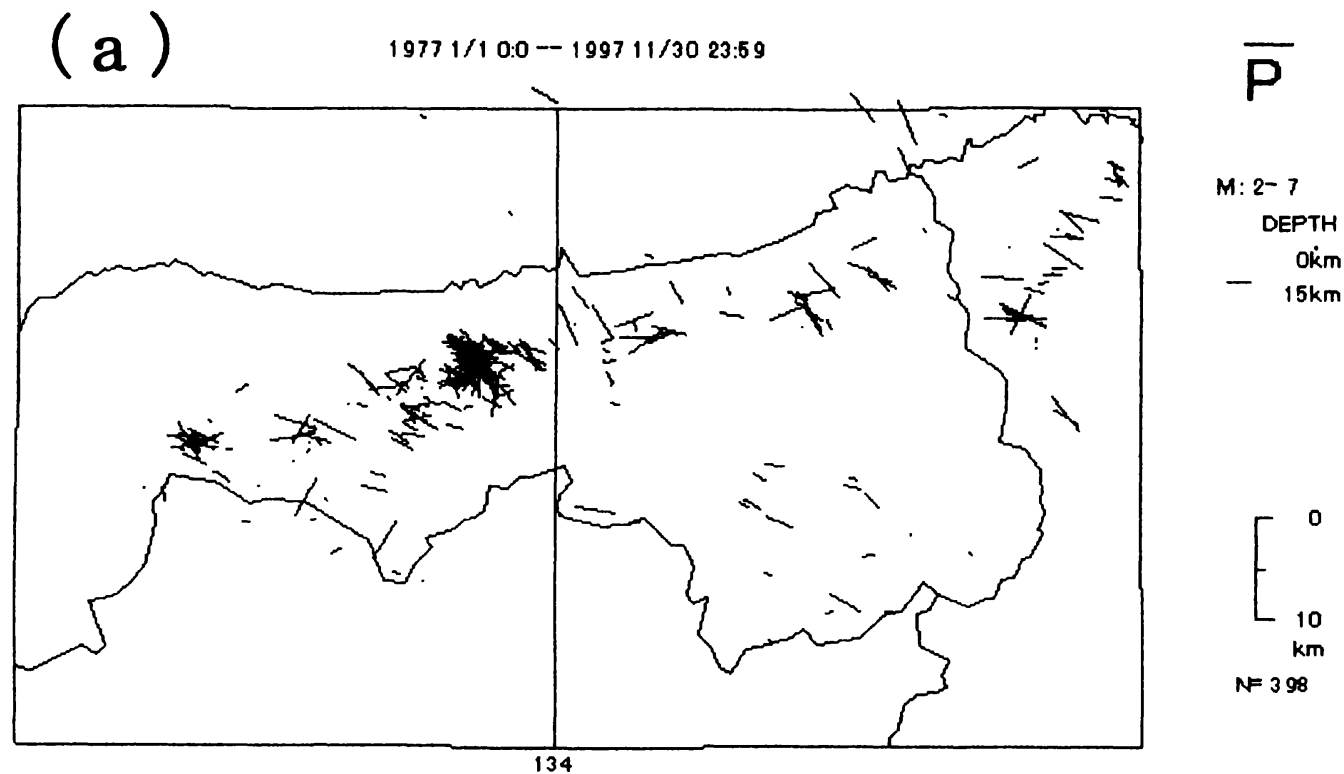

( b )

$19771 / 10: 0--199711 / 3023: 59$

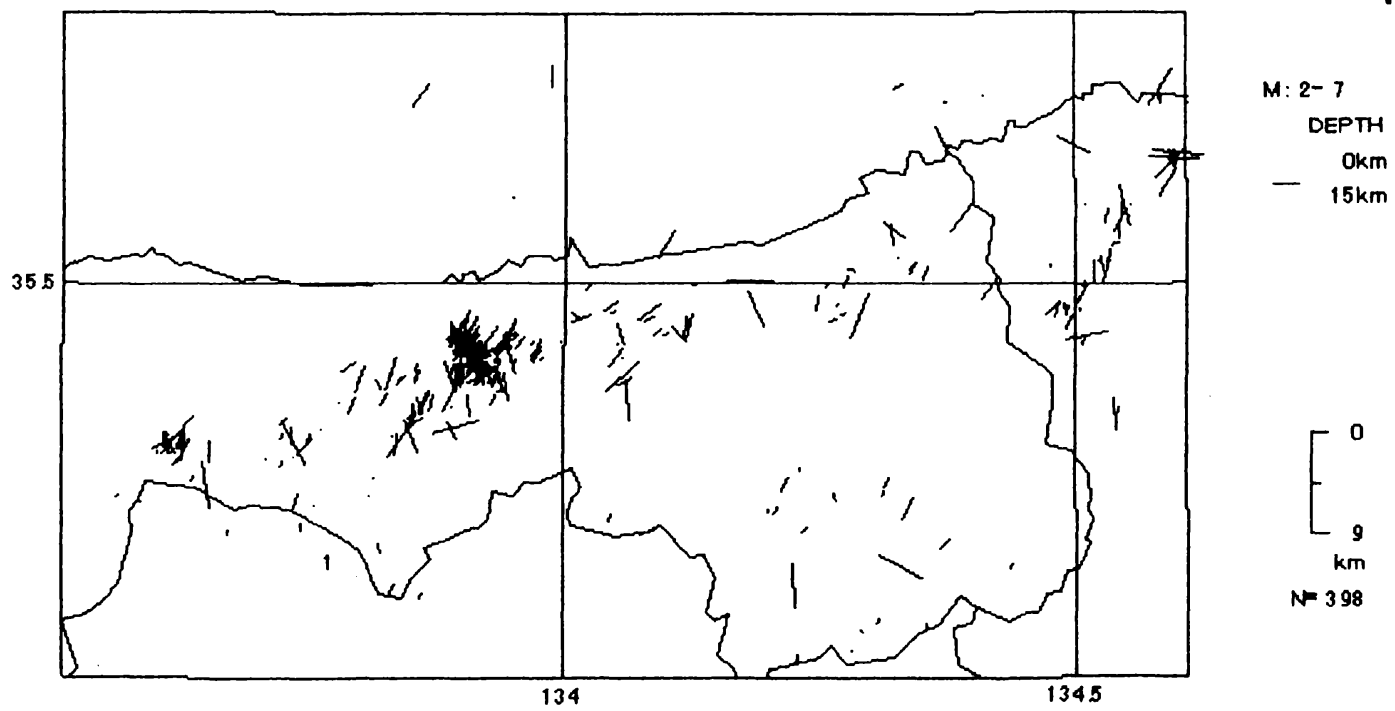

Fig. 6. (a) P-axis distribution of the earthquakes $(M \geqq 2.0)$ from Jan. 1976 to Nov. 1997. (b) T-axis distribution of the earthquakes $(M \geqq 2.0)$ from Jan. 1976 to Nov. 1997. P-and T-axes are shown by thick lines to project on the horizontal plane. 
る.

1977 年から 1993 年までの地震活動は, 低活動で 3 回の群発地震活動が南西から北東へ 10 数年間で移動 した $(1977 \rightarrow 1982 \rightarrow 1992)$. しかし, 1994 年は地震活動 が活発化し, 1 年間で地震活動域が北東から南西 $(\mathrm{F} 1 \rightarrow$ F2 $\rightarrow$ F3) 一移動した (Fig. 5). 長い期間の一定方向の 移動が, 1994 年の 1 年間で全く逆の移動となっている. 1995 年以降は再び活動が低下している [西田・他 (1998)].

この地域全体では, 海岸に沿った地震活動域が顕著で あるが，それぞれの地域で活動域の分布に違いが見ら れる. 解析期間中では, 1983 年の鳥取県中部の地震 $(M$ 6.2) が最大の地震活動である.

\section{§3. 解析データ及び解析方法}

鳥取県東部・中部地域及びその周辺は，鳥取観測所に より，長期間精度のよい観測が実施されている. 1976 年 5 月 1 日よりテレメーター・システムが導入され, 鳥 取県下では鳥取, 鹿野, 倉吉, 智頭に観測点が設置され, さらに, 1980 年から鳥取県西部の多里観測点と岡山県 中部の久米観測点が加わり, 精度の高い微小地震観測が 行われるようになった. 1977 年 1 月から, 1997 年 11 月までのデータを使用し, 発震機構の解析を行った.

$M \geqq 2.0$ の地震 462 個 (Fig. 2) について, 明瞭な $\mathrm{P}$ 波 の初動方向を読み取り, 押引分布から発震機構を決定し
た. 震源は鳥取観測所で決定された震源要素を使用し た. $\mathrm{P}$ 波初動のデー夕は鳥取観測所のデー夕を基本にし $\tau$, 京都大学防災研究所附属地震予知研究センター阿武 山観測所と, 東京大学地震研究所地震地殼变動観測セン 夕ー広島観測所のデータ, さらに, 大阪管区気象台の波 形処理データから $\mathrm{P}$ 波初動方向を読み取り, データファ イルを作成した.

発震機構の解析は明瞭な $\mathrm{P}$ 波初動の押し引き分布を 作成し震源球上に四象限モデルを仮定し, 前田が開発し た方法 [前田 (1988), MAEDA (1992)] により, P 軸, T 軸を決定した。

震源決定, 発震機構の解析に使用した地震波速度構造 は，鳥取観測所が用いている倉吉-花房の人工地震によ る速度構造である. 第 1 首を $5.05 \mathrm{~km} / \mathrm{s}$, 第 2 層を 6.05 $\mathrm{km} / \mathrm{s}$, 第 3 層を $6.60 \mathrm{~km} / \mathrm{s}$, モホ面下の最上部マント ルは $8.00 \mathrm{~km} / \mathrm{s}$ とし，それぞれの層の厚さを $3 \mathrm{~km}, 13$ $\mathrm{km}, 22 \mathrm{~km}$ とした. モ木面の深さは $38 \mathrm{~km}$ である [西 田・他(1976)].

そして, 地域の平均的な地殸応力を次の方法で求め た. Акг (1966) は, 1 つの地震の発震機構を決定するだ けのデータがない場合, ある地域に発生したすべての地 震の $\mathrm{P}$ 波初動デー夕を 1 つの震源球に重ね合わせて, $\mathrm{P}$ 軸, $\mathrm{T}$ 軸を決定し, 平均的な地款応力を求めた。 また, 西田 [NISHIDA (1973), 西田・他 (1976)］は同様の方法 で近畿地方北部, 中国地方東部の平均的な応力場の議論

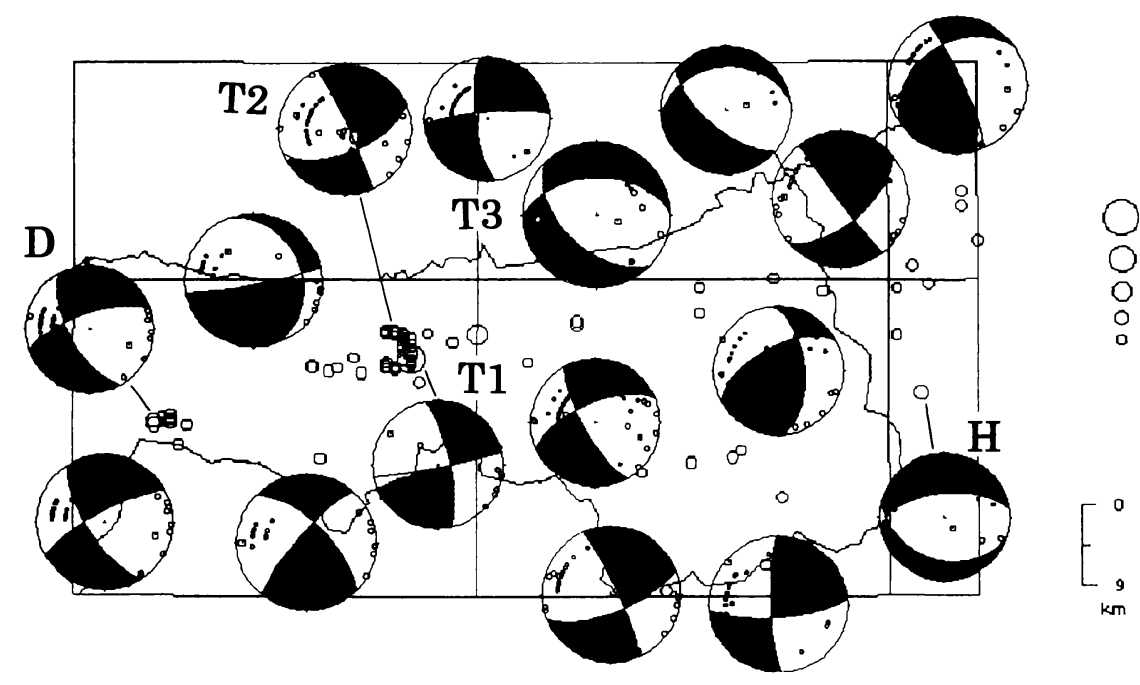

Fig. 7. Distribution of fault plane solutions of large earthquakes, indicated onto the upper hemisphere by equal area projection, and white and black regions on focal sphere represent the dilatation and the compression, respectively. D; the main shock near Mt. Daisen activity, $M$ 4.9, July 2, 1985, T1; the main shock of the 1983 Tottori earthquake, $M 6.2$, Oct. 31, 1983, T3; the induced earthquake, $M 5.7$, Oct. 31, 1983, T2; the largest aftershock, $M 4.7$, Nov. 3, 1983, H; the earthquake near Mt. Hyounosen, $M 4.8$, Nov. 25, 1992. 
を行った.

本研究ではこの方法を基に，ある地域の平均的な $\mathrm{P}$ 軸, $\mathrm{T}$ 軸の分布を求めるため, 決定された地震の $\mathrm{P}$ 軸及 び $\mathrm{T}$ 軸を重ねあわせ, $k$ 值を集中度係数として次のよう に定義した。

$$
k=[N P-N T] / N \times 10
$$

ここで, $N P$ : 点 $\mathrm{Q}\left(\mathrm{Q}^{\prime}\right)$ から角距離 $45^{\circ}$ 内の $\mathrm{P}$ 軸の数
$N T$ : 点 $\mathrm{Q}\left(\mathrm{Q}^{\prime}\right)$ から角距離 $45^{\circ}$ 内の $\mathrm{T}$ 軸の数 $N$ : その地域の地震の数

点 $\mathrm{Q}$ と点 $\mathrm{Q}^{\prime}$ は震源球上で中心から対称な位置にあ る. 震源球上に等 $k$ 值線を引いて $\mathrm{P}$ 軸, $\mathrm{T}$ 軸の集中度の コンタマップを描く．そして $k$ 值が最大となる方向が平 均的主圧力方向, 最小となる方向が平均的主張力方向と する, すなわちその地域の地殼に作用する平均的な主応
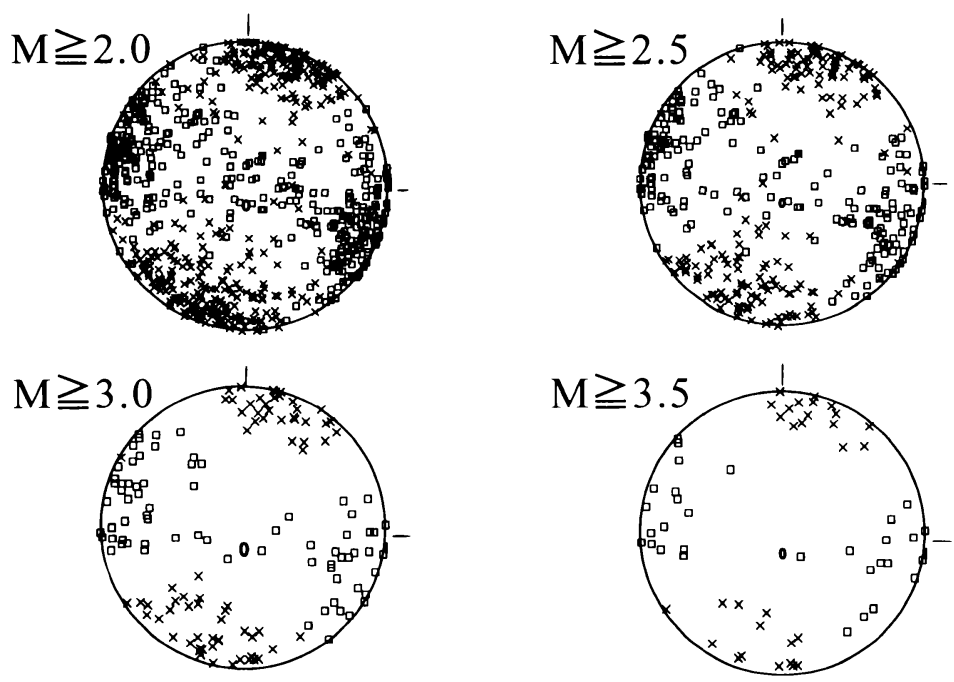

口P-axis $\times$ T-axis
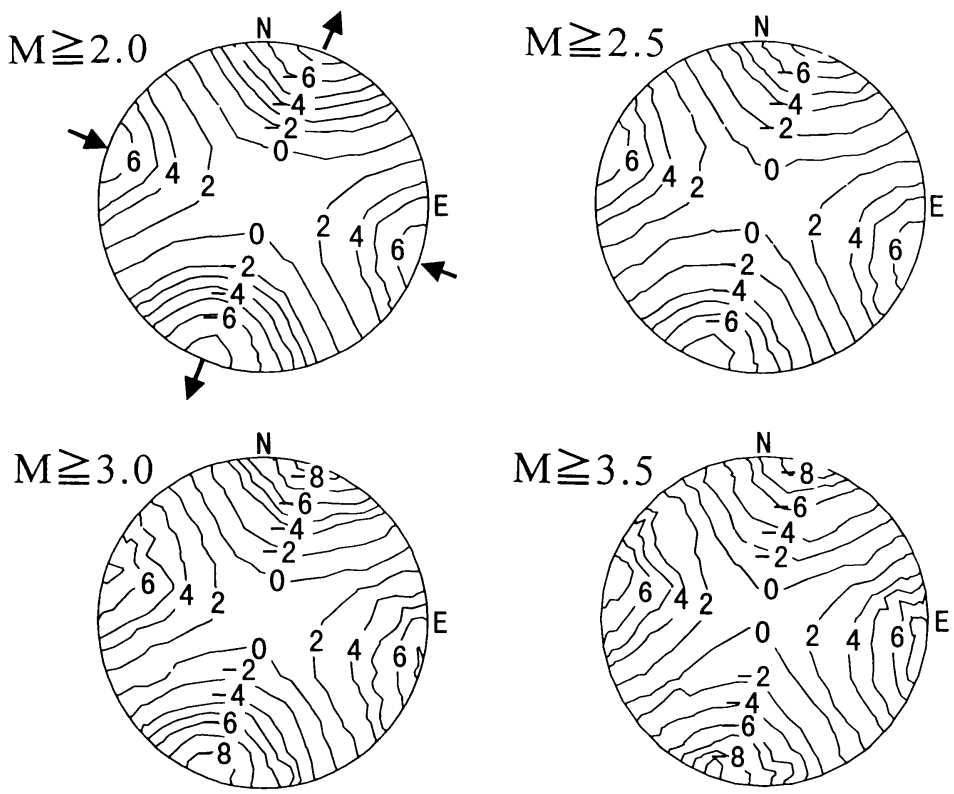

Fig. 8. Upper: Distribution of P-and T-axes for each magnitude, plotted on the upper hemisphere by the equal area projection. Squares and crosses represent $\mathrm{P}$ - and T-axes, respectively. Lower: Diagrams show contour maps of equal $k$ values in the same projection, and arrows show directions of the most probable focal stress pattern. 
力の方向を求めることができる.

\section{§4. 発震機構から求められる地殼応力}

今回, $M \geqq 2.0$ 以上の地震 462 個のうち 398 個で発震 機構が決定された，地域全体の地震 $(M \geqq 2.0)$ の分布 (Fig.6) では, 主圧力 (P 軸) は東西方向でなく, 時計回 りに回っている傾向が読み取れる. 多くの解は鳥取県中 部の地震（1983 年, M 6.2）の地震群に集中している.
また，東部地域は地震が少なく，P 軸のばらっきあ大き いことが見える．兵庫県北西域では $\mathrm{P}$ 軸の整列が見える が， T 軸はばらつきが大きい.

この地域で大きい地震の発震機構を Fig. 7 に示す.メ カニズム D は, 大山付近の活動の本震でほぼ東西方向の $\mathrm{P}$ 軸を示している。これは 1983 年鳥取県中部の地震と 同じ地壳応力を示す. メカニズム T1 は鳥取県中部地域 の本震, $\mathrm{T} 3$ は本震 3 分半後の青谷町の地震, $\mathrm{T} 2$ は最大
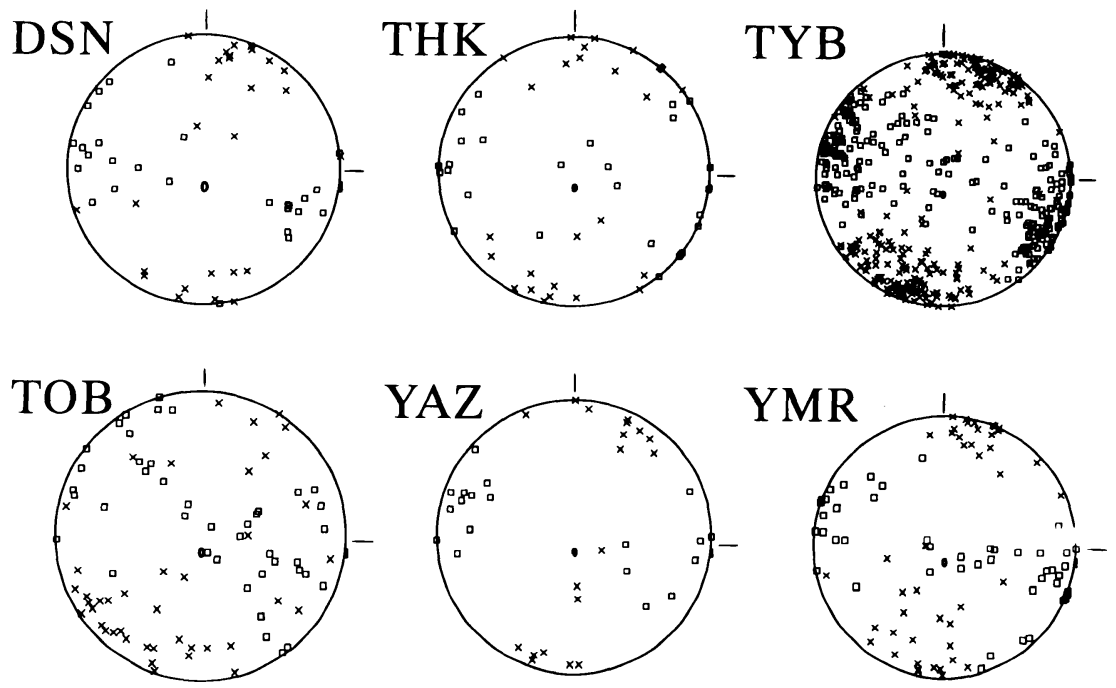

P-axis $\times$ T-axis
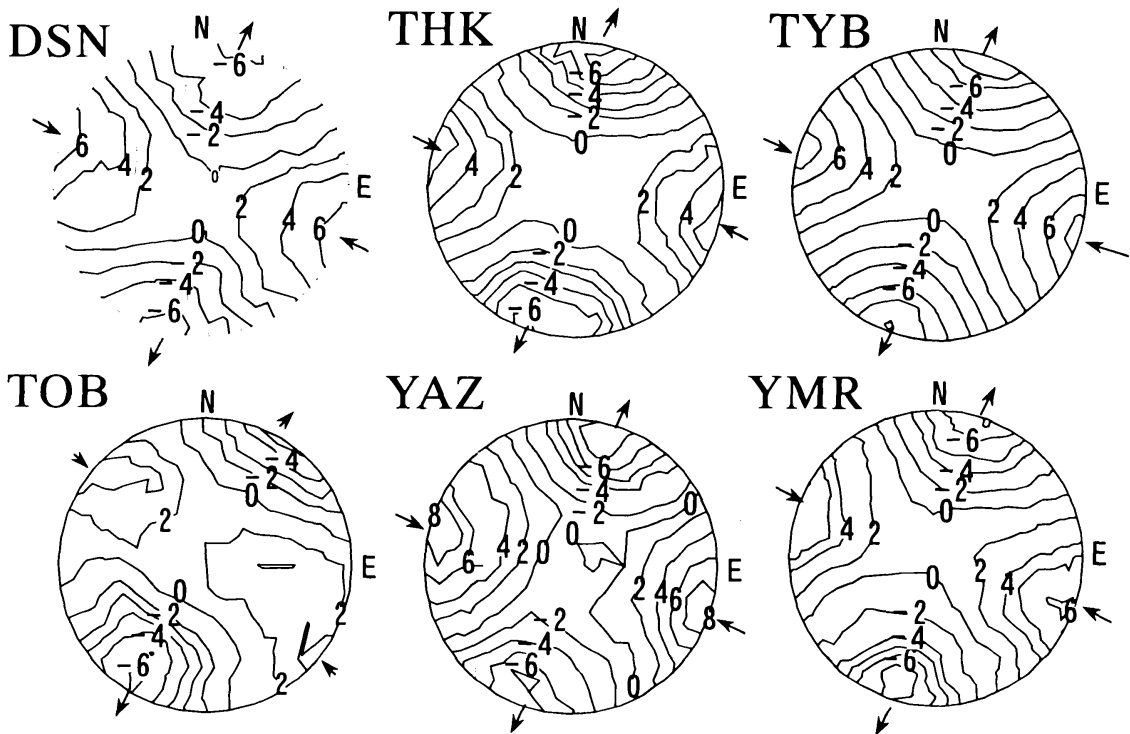

Fig. 9. Upper: Distribution of P-and T-axes for each region on the upper hemisphere by the equal area projection, squares and crosses represent $\mathrm{P}$ and $\mathrm{T}$ axes, respectively. Lower: Diagrams show contour maps of equal $k$ values and directions of the most probable focal pattern (arrows) for each region in the same projection. 
余震である.この地震活動では横ずれ断首型の発震機構 が卓越しており, 東西方向またはやや時計迴りに回転し た主圧力方向とそれに直交する主張力方向を示す．しか し, 正断層型を示す地震む少ないがあり, 地下断層系の 複雑さを示している. 1993 年の兵庫県北西部の地震 $(\mathrm{H})$ は, 正断層型の発震機構で, 余震をほとんど伴わない単 発型の活動で, 特異な地震である. 逆断層の要素は多く の地震で見られるが, 全体として横ずれ成分が卓越して いる地震が多い.

次に, マグニチュード別にすべての発震機構から求め られた P 軸, T 軸を重ね合わせた (Fig. 8). P 軸, T 軸の ばらつきと集中が見られるので, 集中度係数 $k$ のコンタ マップを作成して平均的な $\mathrm{P}$ 軸と $\mathrm{T}$ 軸の方向を求めた. これらから、マグニチュードが小さい地震ほどばらつき が大きく, マグニチュードが大きくなるに従い, 横ずれ 成分が卓越することがうかがえる.これはマグニチュー ドの小さい地震が地款内の局所的な地下断層の形状など に影響を受け易いためと推定される. しかし，それぞれ のコンタマップから求められた $\mathrm{P}$ 軸や $\mathrm{T}$ 軸の集中する 方向はほとんど変わらず, $\mathrm{P}$ 軸は東西方向から約 $20^{\circ}$ 時 計回りに回った方向に, T 軸は南北方向からこれも約 $20^{\circ}$ 時計回りに回った方向で, ほぼ水平に求まっている. したがって, その地域の地震を起こす地殼応力の方向は マグニチュードに依存せず, 一定方向である. 地震の発 震機構から求められた地殻応力について, 大地震ではば らつきが小さく, 微小地震クラスでは大きいことは, 小 さい地震ほどその地域の構造, 例えば地下断層系, の影 響を多く受けていると考えられる.

鳥取県東部・中部地域を 6 つ域に分割して，それ ぞれの地域についてその特徵を分析する. 中部地域は大 山付近 (DSN), 東伯 (THK) と中部 (TYB) に分け, 東部
地域を東部 (TOB), 八頭 (YAZ) と兵庫県西北部 (YMR) と分割し, 地域別の $\mathrm{P}$ 軸, $\mathrm{T}$ 軸の分布と $k$ 值のコンタ マップを示す (Fig. 9). 東部地域を除く 5 つの地域では, $\mathrm{P}$ 軸や $\mathrm{T}$ 軸の集中する方向はほぼ全体と同じく，P 軸は 東西方向から約 $20^{\circ}$ 時計回りに回った方向に, $\mathrm{T}$ 軸も南 北方向から約 $20^{\circ}$ 時計回りに回った方向で, ほぼ水平方 向である. 地域全体を論じると中部 (TYB) の地震数が 多く，この地域の性質が全体を代表するが，他の地域で あ同じような地殼応力を示すことはこの地域全体の地殼 応力が整列していることを示している.

一方, 東部 (TOB) は鳥取地震の地震断層の鹿野・吉 岡断層周辺の地震群で, これらの地域の中で唯一, $\mathrm{P}$ 軸 が東西方向から約 $45^{\circ}$ 時計回りに回った方向, $\mathrm{T}$ 軸は南 北方向からこれも約 $30^{\circ}$ 時計回りに回った方向に集中し ている. しかし, 集中係数である $k$ 值は小さいことは, ばらつきが大きいことを示している.

次に, 解析期間中最大地震の 1983 年鳥取県中部の地 震は断層周包の応力場が NiSHIDA $(1988,1990)$ により 詳細に議論され, 地款応力の変化はなかったとの結論を 得ている. しかし, 発震機構の時間的な変化が見られた 例が 2 つあった. 1 つは, 大山付近 (DSN) で $M \geqq 2.0$ の 地震を対象にして, 1985 年の活動の前後 3 期に分けた. (1) 1977 年 1 月 1985 年 5 月, (2) 1985 年 6 月 1985 年 9 月, (3) 1985 年 10 月〜 1997 年 11 月, それ ぞれの期間の $\mathrm{P}$ 軸, T 軸の分布を Fig. 10 に示した. 活 動中の $\mathrm{P}$ 軸, T 軸はそれぞれ $\mathrm{N} 110^{\circ} \mathrm{E}, \mathrm{N} 20^{\circ} \mathrm{E}$ と集中し ているが, 活動前, 活動後は地震の数は少なくなり, $\mathrm{P}$ 軸， T 軸の集中は見られない. 2 つ目は兵庫県北西部 地域での地震活動の移動に伴う P 軸, $\mathrm{T}$ 軸の時間変化で ある. 1977 年〜1993 年の地震と 1994 年〜1997 年 11 月の地震の $\mathrm{P}$ 軸, $\mathrm{T}$ 軸の分布を Fig. 11 に示した. 1977
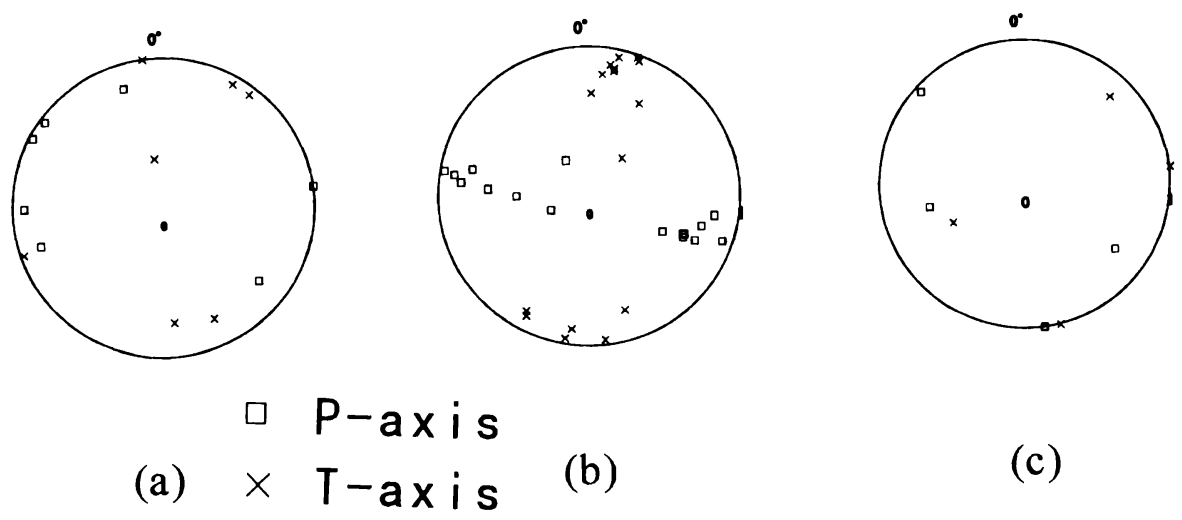

Fig. 10. Distribution of P-and T-axes on the upper hemisphere in DSN area are shown by the equal area projection, squares and crosses represent $\mathrm{P}$ and $\mathrm{T}$ axes, respectively. (a), (b) and (c) are those before, during and after the seismic activity in 1985. 

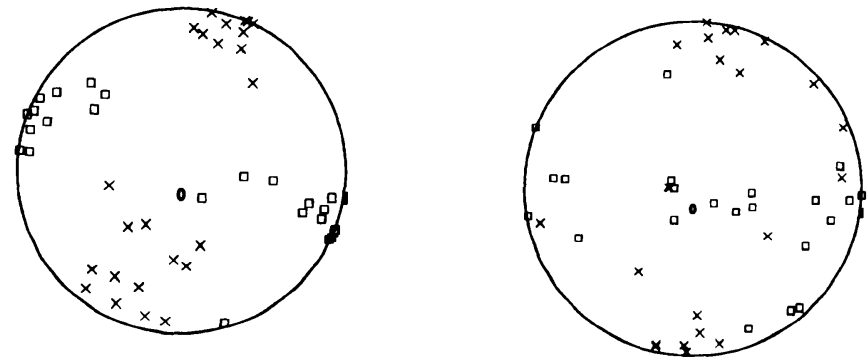

(a)

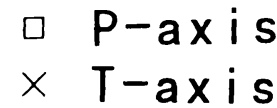

(b)

Fig. 11. Distribution of P- and T-axes on the upper hemisphere in YMR area shown by the equal area projection, squares and crosses represent $\mathrm{P}$ - and $\mathrm{T}$-axes, respectively. (a) Indicate the period from 1977 to 1993 , and (b) indicate the period from 1994 to 1997.

年〜1993 年は地震活動が南西から北東へと移動した期 間であり, 平均的な P 軸, T 軸はそれぞれ WNW-ESE, NEN-SWS 方向である. また, 兵庫県南部地震の前年の 1994 年から 1997 年 11 月までは北東から南西へと移 動した期間であり， $\mathrm{P}$ 軸， $\mathrm{T}$ 軸はそれぞれ反時計回りに 変化している.この時間変化は兵庫県南部地震前後の広 域応力場変化の 1 つと屯考えられる.

\section{§5. 議論}

この地域の鳥取地震（1943 年, $M 7.2)$ の前震・余震 の発震機構の研究は, 市川 (1968) が気象庁データから 詳細な解析を行い， $\mathrm{P}$ 軸の方位平均は $\mathrm{N} 66^{\circ} \mathrm{W}$ と求めら れている.また, 微小地震データから, HASHIZUME (1970) が null vector を垂直と仮定して，P 波初動分布 を重ね合わせて, $\mathrm{P}$ 軸の方位平均を $\mathrm{N} 60^{\circ} \mathrm{W}$ と求めた。 NISHIDA（1973）はP 波初動を重ね合わせる方法を用い て, $\mathrm{P}$ 軸は水平で $\mathrm{N} 80^{\circ} \mathrm{W}$ と求めている. 西南日本内帯, 近畿地方北部ではほぼ東西方向の主圧力が求まるのに, この地域では時計回り方向にそれより約 $10^{\circ} \sim 30^{\circ}$ 回 転している結果が求まっている. 今回の解析でも, 地域 全体の平均的な $\mathrm{P}$ 軸, $\mathrm{T}$ 軸それぞれの方位は $\mathrm{N} 70^{\circ} \mathrm{W}$, $\mathrm{N} 20^{\circ} \mathrm{E}$ と求められ, 既往の研究とほぼ同じ結果を得て いる.

1943 年鳥取地震の発震機構の $\mathrm{P}$ 軸, $\mathrm{T}$ 軸の方向はそ れぞれ, $\mathrm{N} 74^{\circ} \mathrm{W}, \mathrm{N} 26^{\circ} \mathrm{E}$ で水平方向であり，この地域を 支配する $\mathrm{P}$ 軸, $\mathrm{T}$ 軸の方向とほぼ一致する [東京大学地 震研究所 (1975)] (Fig. 12). 我々の解析では鳥取県東 部・中部地域における平均的な $\mathrm{P}$ 軸, $\mathrm{T}$ 軸の方向は, 東 部地域を除いて WNW-ESE, NEN-SWS であり, 東部 地域は NW-SE, NE-SW であるという結果が得られて いる.

地域的に見てみると, 鳥取地震の震源地であり, 吉

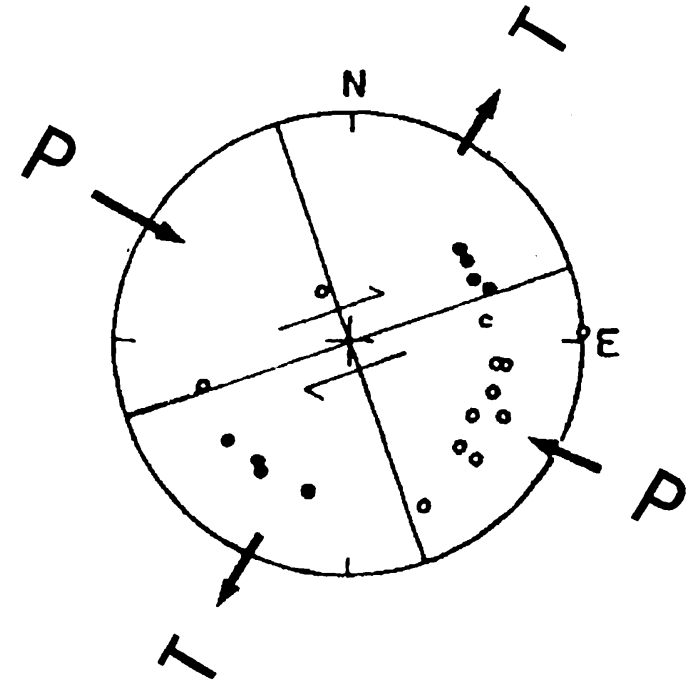

Fig. 12. Focal mechanism of the Tottori earthquake, $M 7.2$, Sept. 10, 1943, projected onto the upper hemisphere of the Wulff net. Solid and open circles represent the compression and the dilatation, respectively. Arrows show the P-and the T-axis.

岡・鹿野断層がある東部地域の平均的な主応力方向は全 体から少しずれ，しかも $k$ の值が小さい. しかし, 平均 的な発震機構から求められた節面の走向は $\mathrm{N} 90^{\circ} \mathrm{E}$ であ り，鳥取地震の地震断層の走向がほぼ東西であることと 一致していることを考えれば, 地下断首系を明瞭に表現 しているとも言える.ここは, 1943 年鳥取地震の震源 断層の破壊のスタート地点であり, UMEDA (1981) のい うブライトスポットに当たる地域である. 地殼応力から 地震断層の走向と同じであること，比較的大きな地震が 少なく，ばらつきも大きいことは現在でも破壊が激し かった地殻の性質を残していると推定される，また，鳥 


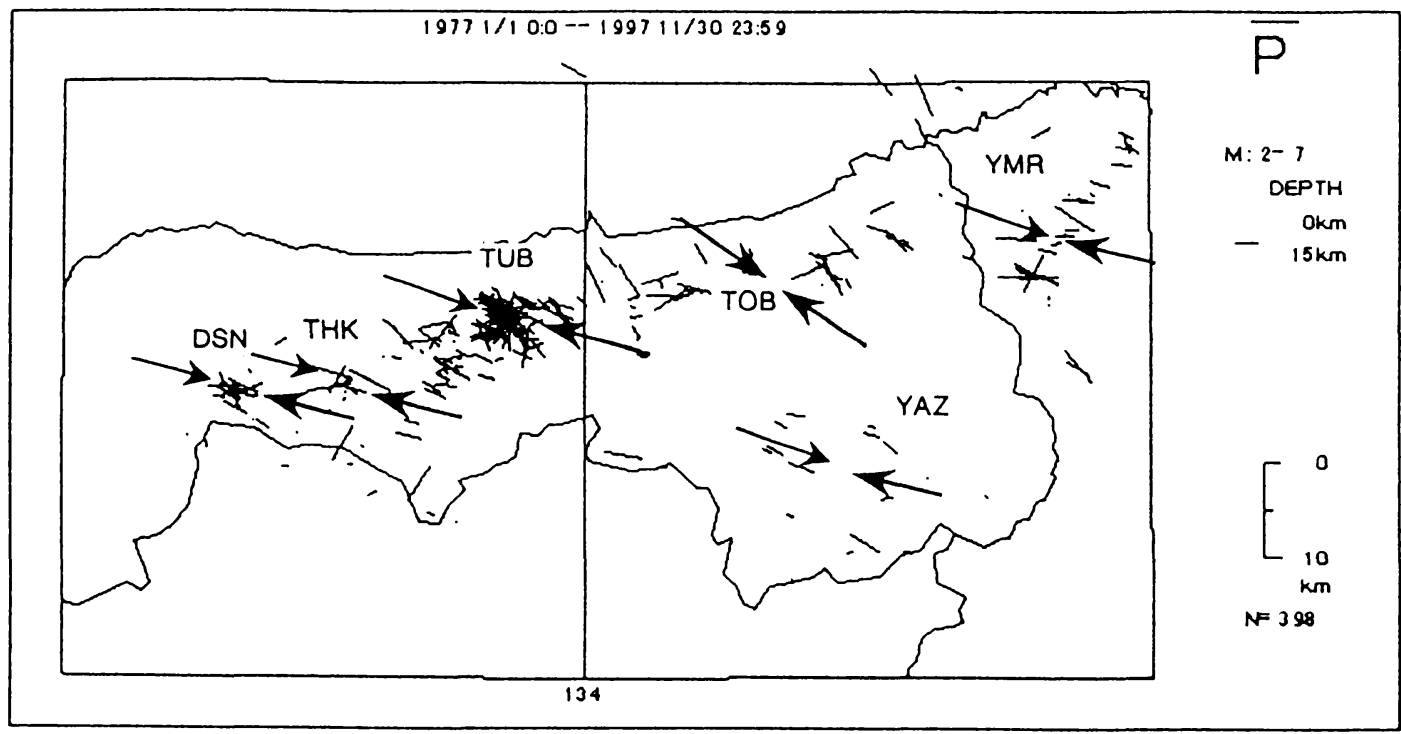

Fig. 13. Stress pattern for each regions are shown by thick arrows with P-axis distribution of the earthquakes $(M \geqq 2.0)$ projected on the horizontal plane, and are shown thin lines.

取地震の余震域の西端に位置している中部地域では, 1983 年鳥取県中部地震が，鳥取地震の余震域の西端域 に発生しており, 鳥取地震の東西走向の断層と共役な, 北西 - 南東走向をあつ左横ずれ断層である。 この共役な 断層の出現は, この地域にせん断応力が集中・増加した 結果と思われる。 その主応力はこの地域を支配する広域 応力場とほぼ一致している. 鳥取県東部・中部の各地域 の平均的な主圧力の方向とそれぞれの地震の主圧力方向 分布を示す (Fig. 13).

山陰地域の平均的な主圧力の方向がなぜ WNW-ESE であるかは，山陰地域にある第四紀火山の並びが東西, 広域変成岩帯の走向も東西走向, 地震活動帯の走向も同 様であるなど，広域応力場の形成過程を総合的に解明す ることが必要である.フィリピン海プレートの沈み込み による北西 - 南東の運動に加えて，ユーラシアプレート である西南日本の東進という新しい観測事実があり [塚 原・小林 (1990)], その詳細な応力場の解析・検討は今 後の課題である.

\section{§6. まとめ}

以上のことから，次のような事柄が明らかとなった。

1）この地域の地震の発震機構から求められた広域応 力場の主応力の方向は, 鳥取地震から求められた主応力 の方向とほぼ一致し, $\mathrm{P}$ 軸は $\mathrm{N} 70^{\circ} \mathrm{W}, \mathrm{T}$ 軸は $\mathrm{N} 20^{\circ} \mathrm{E}$ で 水平方向である.

2) 鳥取地震の地震断層付近では地下断層系に起因す る平均的な $\mathrm{P}$ 軸, $\mathrm{T}$ 軸の方向は, ばらつきが大きい, し
かし，平均すれば地震断層の形成応力方向と一致する.

3）ママグニチュード別平均では， $\mathrm{P}$ 軸, $\mathrm{T}$ 軸の方向は 変わらないが, マグニチュードが小さくなるとばらつき が大きくなる，地震が小さいほど地下断首系の影響を受 けることを示している.

\section{謝辞}

関東学院の前田直樹助教授には発震機構決定のプログ ラムの提供と解析のご指導をいただきました. 京都大学 防災研究所地震予知研究セン夕ーの片尾 浩博士, 阿武 山観測所の浅田照行技官には阿武山観測所のデータを提 供していただき，またいろいろご指導していただきまし た. 東京大学地震研究所地震地款観測センター広島観測 所の三浦勝美技官には, 広島観測所のデータの提供や施 設の使用などご協力いただきました。ここに記して感謝 いたします，また，丁寧に査読をしていただいた查読者 の方々に感謝いたします。

\section{文献}

АкІ, К., 1966, Earthquakes Generating Stress in Japan for the Years 1961 to 1963 Obtained by Smoothing the First Motion Radiation Patterns, Bull. Earthq. Res. Inst., 44, 447-471.

浜田信生, 1987, 日本列島内部に発生した被害地震に伴 う地震活動の再調査とその地震学的意義, 気象研究所 研究報告, 38, 77-156.

Hashizume, H., 1970, Investigation of microearthquakes-on earthquake occurrence in the crust-, 
Bull. Disas. Prev. Res. Inst., Kyoto Univ., 20, 65-94. 市川政治, 1968, 日本付近の地震のメカニズムに関する 統計的研究之二・三の問題, 研究時報, 18, 1-72.

伊藤 潔, 1990, 西南日本の地震活動とテクトニクス, 地震 $2,43,555-569$.

KANAMORI, H., 1972, Determination of Effective Tectonic Stress Associated with Earthquake Faulting. The Tottori Earthquake of 1943, Phys. Earth. Planet. Interiors, 5, 426-434.

Katao, H., N. Maeda, Y. Hiramatu, K. Ito and S. NAKAo, 1995, Detailed Mapping of Focal Mechanisms in/around the 1995 Hyogo-ken Nanbu Earthquake Rupture Zone, J. Phys. Earth, 45, 205-119.

活断首研究会, 1980, 日本の活断層, 東京大学出版会.

Kishimoto, Y. and R. NishidA, 1973, Mechanisms of Microearthquakes and their Relation to Geological Structures, Bull. Disas. Prev. Res. Inst., Kyoto Univ., 23, 1-25.

前田直樹, 1988, 地震の発生機構の決定法, 地震 2, 41, 323-333.

MaEdA, N., 1992, A Method of Determining Focal Mechanisms and Quantifying the Uncertainty of the Determined Focal Mechanisms for Micro Earthquakes, Bull. Seism. Soc. Am., 82, 6, 24102429.

松山和也, 1989,1985 年大山付近の地震について, 鳥取 大学教育学部卒業論文.

NishidA, R., 1973, Earthquake Generating Stress in Eastern Chugoku and Northern Kinki District, Southwest Japan, Bull. Disas. Prev. Res. Inst., Kyoto Univ., 22, 197-233.

西田良平・中尾節郎・矢部 征, 1976 , 山陰地方の地震
活動, 京都大学防災研究所年報, 17, 69-81.

西田良平, 1983 , 山崎断層周边の微小地震の発震機構に ついて，鳥取大学教養部紀要，17, 209-234.

Nishida, R., 1988, The Mechanism of Occurrences of the Main Shock and Aftershocks of the 1983 Tottori Earthquake and their Relation to the Tectonic Stress Field, J. General Education, Tottori Univ., 22, 77-116.

NishidA, R., 1990, Characteristics of the 1983 Tottori earthquake sequence and its relation to the tectonic stress field, Tectonophysics, 174, 257-278.

西田良平・黒川 泰・赤木三郎, 1993,1943 年鳥取地 震に伴う吉岡・鹿野断層とその周辺の地変について, 鳥取大学教養部紀要, 27, 187-226.

西田良平・中尾節郎・石賀 崇・西上欽也，1998, 鳥取 県東部及びその周辺の地震活動について, 京都大学防 災研究所年報, 41, 1-9.

竹内文朗 - 佃 為成 - 西田良平 - 中尾節郎 - 渋谷拓郎 渡辺邦彦・西上欽也・尾池和夫, 1986,1985 年大山 火山付近に発生した群発地震について, 京都大学防災 研究所年報, 29, 39-47.

瀧谷哲司, 1991, 鳥取県東部及び周辺の地震活動につい $\tau$, 鳥取大学教育学部卒業論文.

東京大学地震研究所, 1975 , 東京大学地震研究所研究連 報第 9 号 図説 日本の地震 1872 年 1972 年, 東 京大学地震研究所, 80-81, vb.

塚原弘昭・小林洋二, 1990, 本州中 - 西部の地壳応力, 地球惑星科学関連学会 1990 年合同大会講演予稿集, 79 .

UMEDA, Y., 1981, An earthquake source model with a ripple generating core, J. Phys. Earth, 29, 341-370. 